\title{
Distribution of maternal red cell antibodies and the risk of severe alloimmune haemolytic disease of the foetus in a Chinese population: a cohort study on prenatal management
}

\author{
Si Li ${ }^{1,2}$, Zhiming $\mathrm{He}^{2}$, Yanmin Luo ${ }^{2}$, Yanli $\mathrm{Ji}^{3}$, Guangping $\mathrm{Luo}^{3}$, Qun Fang ${ }^{2^{*}}$ and Yu Gao ${ }^{\text {* }^{*}}$
}

\begin{abstract}
Background: Haemolytic disease of the foetus and newborn (HDFN) is the most common aetiology of haemolytic anaemia and hyperbilirubinaemia in foetuses and neonates. Studies on the distribution of antibodies that cause haemolytic disease of the foetus (HDF) in China are limited, and the effects of multiple antibodies on the severity of HDF need further evaluation.

Methods: An observational cohort study from January 2005 to December 2019 was conducted in two hospitals affiliated with Sun Yat-sen University. Maternal red cell alloimmunization was identified by the Guangzhou Blood Centre. In total, 268 pregnant woman-foetus pairs were divided into four groups according to the type of maternal alloantibodies: anti-D, anti-D combined with other antibodies, other single-antibody and other multiple antibodies. The obstetric history, antibody characteristics, incidence of severe HDF and foetal outcomes were collected and compared. Logistic regression analysis of the risk factors for HDF and survival analysis of the severe HDF-free interval were conducted.

\footnotetext{
*Correspondence: fangqun@mail.sysu.edu.cn; gaoy57@mail.sysu.edu.cn

${ }^{2}$ Foetal Medicine Centre, Department of Obstetrics and Gynaecology, the

First Affiliated Hospital of Sun Yat-sen University, Guangdong 51000 Guangzhou, China

'Department of Obstetrics, the Sixth Affiliated Hospital of Sun Yat-sen University, 510655 Guangzhou, Guangdong, China

Full list of author information is available at the end of the article
}

(C) The Author(s). 2020 Open Access This article is licensed under a Creative Commons Attribution 4.0 International License, which permits use, sharing, adaptation, distribution and reproduction in any medium or format, as long as you give appropriate credit to the original author(s) and the source, provide a link to the Creative Commons licence, and indicate if changes were made. The images or other third party material in this article are included in the article's Creative Commons licence, unless indicated otherwise in a credit line to the material. If material is not included in the article's Creative Commons licence and your intended use is not permitted by statutory regulation or exceeds the permitted use, you will need to obtain permission directly from the copyright holder. To view a copy of this licence, visit http://creativecommons.org/licenses/by/4.0/. The Creative Commons Public Domain Dedication waiver (http://creativecommons.org/publicdomain/zero/1.0/) applies to the data made available in this article, unless otherwise stated in a credit line to the data. 


\begin{abstract}
(Continued from previous page)
Results: Anti-D was the most common cause of HDF, followed by anti-M. No anti-K- or isolated anti-c-associated HDF was found. The incidence of severe HDF was higher in the group with anti-D combined with other antibodies than in the group with anti-D alone $(P=0.025)$, but no significant difference was found in haemoglobin level and reticulocyte count in the anaemic foetuses between these two groups. Foetuses in the other single-antibody group had a lower reticulocyte count $(P=0.007)$, more IUTs $(P=0.007)$ and an earlier onset of severe HDF $(P=0.012)$. The maximum antibody titre was significantly lower in the other single-antibody group than in the anti-D group $(P<0.001)$. A high maternal antibody titre $(P<0.001)$, multiple affected pregnancies $(P<0.001)$ and other single-antibody $(P=0.042)$ were independent risk factors for HDF. A higher reticulocyte count $(P=0.041)$ was an independent risk factor for severe HDF in anaemia foetuses affected by Rh(D) alloimmunization.
\end{abstract}

Conclusions: The distribution of HDF-associated antibodies in China is different from that in Western countries. Other single non-Rh(D) antibodies could increase the risk of HDF, and anti-D combined with other antibodies would not influence the severity of foetal anaemia compared with anti-D alone.

Keywords: alloimmunization, haemolytic disease of the foetus, Chinese, foetal anaemia, multiple antibodies

\section{Background}

Haemolytic disease of the foetus and newborn (HDFN) is the most common aetiology of haemolytic anaemia in foetuses and hyperbilirubinaemia in neonates[1]. As the widespread prophylactic use of anti-D immunoglobulin has greatly decreased the incidence of $\mathrm{Rh}(\mathrm{D})$ alloimmunization from 16 to $0.3 \%$ in Western countries[2, 3], the incidence of HDFN caused by non-Rh(D) antibodies has increased to $2.8 \%$ o $3.3 \%$ [4-6]. However, the incidence of anti-D-related HDFN still contributes to the morbidity and mortality of foetuses and newborns in China[7]. A total of $60.8 \%$ of haemolytic disease is caused by anti$\mathrm{D}$, followed by anti-E, anti-c and antibodies in the MNS system, during the neonatal period $[8,9]$. Thus far, the distribution of non-ABO antibodies that cause haemolytic disease of the foetus (HDF) in China is not well known. In addition, some women have multiple red cell antibodies, which might lead to a more complicated situation during pregnancy management than when a single red cell antibody is present. Some studies have found that foetuses affected by multiple antibodies need more interventions than those affected by only anti-D[10]. Thus, the objective of our study was to characterize the distribution of antibodies that cause HDF and to evaluate the effects of different antibodies on the severity of HDF in a Chinese population.

\section{Methods}

\section{Study population}

This was a retrospective two-centre cohort study including pregnant women with non-ABO red cell alloimmunization and their foetuses in the First Affiliated Hospital and the Sixth Affiliated Hospital of Sun Yat-sen University from January 2005 to December 2019. All patients provided written informed consent for each medical intervention. The Guangzhou Blood Centre identified the antibodies responsible for red cell alloimmunization. We screened the alloantibodies in pregnant women based on the following criteria: (1) having $\operatorname{Rh}(\mathrm{D})$ negative phenotype; (2) having previous adverse pregnancy outcomes, including recurrent abortion, foetal demise, and hydrops fetalis; (3) identification of unexpected alloantibodies in ABO blood typing; and (4) having a previous history of blood transfusion. The commercial panel of reagent cells (Immucor, Norcross, GA, USA) with the saline tube test and an indirect antiglobulin test (IAT) with the DG Gel Coombs card (GRIFOLS, Barcelona, Spain) were used for antibody screening and identification. When immunoglobin M (IgM) alloantibody was detected, DTT $(0.01 \mathrm{~mol} / \mathrm{L})$ was used to destroy the IgM antibody first and then IgG alloantibody was determined by IAT using the tube method. The titre of IgG was determined by the IAT method using the reagent cells in the DG Gel Coombs card (GRIFOLS, Barcelona, Spain) after incubation at $37^{\circ} \mathrm{C}$ for $15 \mathrm{~min}$. We included women with IgG red cell antibodies. For the women both had IgM and IgG, only the titre of IgG was recorded in this study. The antenatal diagnostic criteria for HDF were as follows: (1) the detection of non-ABO IgG antibodies in the maternal serum and corresponding maternal-foetal blood group incompatibility; (2) foetal anaemia confirmed by cordocentesis or an adverse pregnancy outcome, which included hydrops fetalis and foetal demise; and (3) a positive antibody elution test from foetal red blood cells (RBCs), which was direct evidence of causing haemolysis. In cases of missing values, treatment with intrauterine transfusion (IUT), hydrops fetalis and foetal demise were also considered as valid confirmation of clinically relevant HDF. We excluded women and their foetuses based on the following criteria: (1) the woman underwent termination of the pregnancy due to foetal structure or chromosome abnormalities; (2) a woman with alloimmunization had the same blood group phenotype as that of her foetus; (3) the woman had unknown antibodies; or (4) the woman was 
lost to follow-up. Stillbirth cases in this study did not include foetal death due to the discontinuation of treatment and induction of labour. Not all the data were available for each case.

\section{Data collection}

Data on the maternal obstetric history, blood transfusion history, type of alloimmunization, presence or absence of hydrops fetalis, and foetal sex were collected. For the anaemic foetuses, we further collected data on the gestational age at the time of diagnosis of HDF; foetal haemoglobin levels, haematocrit levels, reticulocyte counts, and reticulocyte percent before IUT; the number of IUTs; and foetal outcomes. Women who underwent antibody detection multiple times during the same pregnancy were included as a single entry, and the highest titre was recorded during the whole pregnancy. For the women with multiple antibodies, we recorded the titres of all types of antibodies and used the highest titre into analysis. Regarding the women who were pregnant more than once during the study period, each pregnancy was included in our report. To determine the effects of different alloimmunizations, the patients were classified into four groups according to their antibodies, namely, only anti-D (anti-D group), anti-D combined with other antibodies (anti-D combined with others group), other single-antibody (other single-antibody group) and other multiple antibodies (other multiple antibodies group).

\section{Definition and treatment policy}

A previously affected history was defined by the existence of a previous perinatal loss related to HDFN, a previous need for IUT, or a previous need for neonatal exchange transfusion[11]. Foetal outcomes were defined as the survival of the foetuses and the gestational age at birth.

Foetal anaemia was confirmed by cordocentesis, and the severity of foetal anaemia was categorized based on the haemoglobin concentration expressed as a multiple of the median (MoM) for gestational age as follows: mild $(0.83-0.65 \mathrm{MoM})$, moderate $(0.64-0.55 \mathrm{MoM})$, and severe $(<0.55 \mathrm{MoM})[12]$. The indication for an IUT was a foetal haematocrit less than $30 \%$ [11].

\section{Primary and secondary outcomes}

The primary outcome was the occurrence of severe HDF, which was defined as severe foetal anaemia, hydrops foetalis, stillbirth, or the need for IUT due to maternal alloimmunization[1]. The secondary outcomes were the number of IUTs, the severity of foetal anaemia and the outcomes of the foetuses.

\section{Statistics analysis}

Statistical analysis was performed using SPSS 22.0 statistical software. Quantitative variables are expressed as the medians with the 25th and 75th quartiles or the means with their standard deviations. Chi-square tests or Fisher's exact tests were used for distribution-based comparisons between groups. The t-test was used when the values were normally distributed, while the MannWhitney $U$ test was applied when the values were nonnormally distributed. The potential risk factors for HDF in foetuses with maternal alloimmunization, including previously affected pregnancies per woman, maternal transfusion history, maternal antibody titre, maternalfoetal major $\mathrm{ABO}$ incompatibility and the types of maternal antibodies were analysed by logistic regression analysis. The potential risk factors for severe HDF in foetuses with $\mathrm{Rh}(\mathrm{D})$ alloimmunization, including foetal sex, maternal antibody titre, gestational age at diagnosis, reticulocyte count and combination of maternal anti-D with other antibodies, were also included in the multiple variable analysis. The results are presented as $\mathrm{p}$ values, and a two-sided $p$ value $<0.05$ was regarded as statistically significant. The odds ratios (ORs) with $95 \%$ confidence intervals $(95 \% \mathrm{CIs})$ are also presented in regression analysis. The Kaplan-Meier survival analysis of the survival time free from severe HDF is presented. To determine the short-term differences in this interval between groups, the Breslow method was used. The survival curve was generated by GraphPad Prism 5.0.

\section{Results}

From January 2005 to December 2019, a total of 390 pregnant women were positive for alloantibodies. In total, 122 cases were excluded from our study based on the following criteria: loss to follow-up $(n=110)$, termination of pregnancy due to foetal structural abnormalities $(n=04)$, specific maternal-foetal blood phenotype compatibility $(n=06)$ or unknown antibodies $(n=02)$ (Fig. 1$)$. A total of 268 pregnant women and their foetuses were finally included in our study.

\section{Basic characteristics}

The average age of the included pregnant women was $31.1 \pm 4.3$ years old (the ages of 11 women were unknown). Totally 15 women had more than one pregnancy during the study period and thus were represented more than once in our dataset. The patients in this cohort were divided as follows: anti-D group $(n=$ $203)$, anti-D combined with other antibodies group ( $n=$ $38)$, other single-antibody group $(n=24)$ and other multiple antibodies group $(n=03)$. In the anti-D combined with other antibodies group, there were 28 women with anti-C, 9 with anti-E and 1 with anti-M. The anti-D group had the most women with a history of blood transfusion. The basic information of the four groups is shown in Table 1. The women in the anti-D combined 


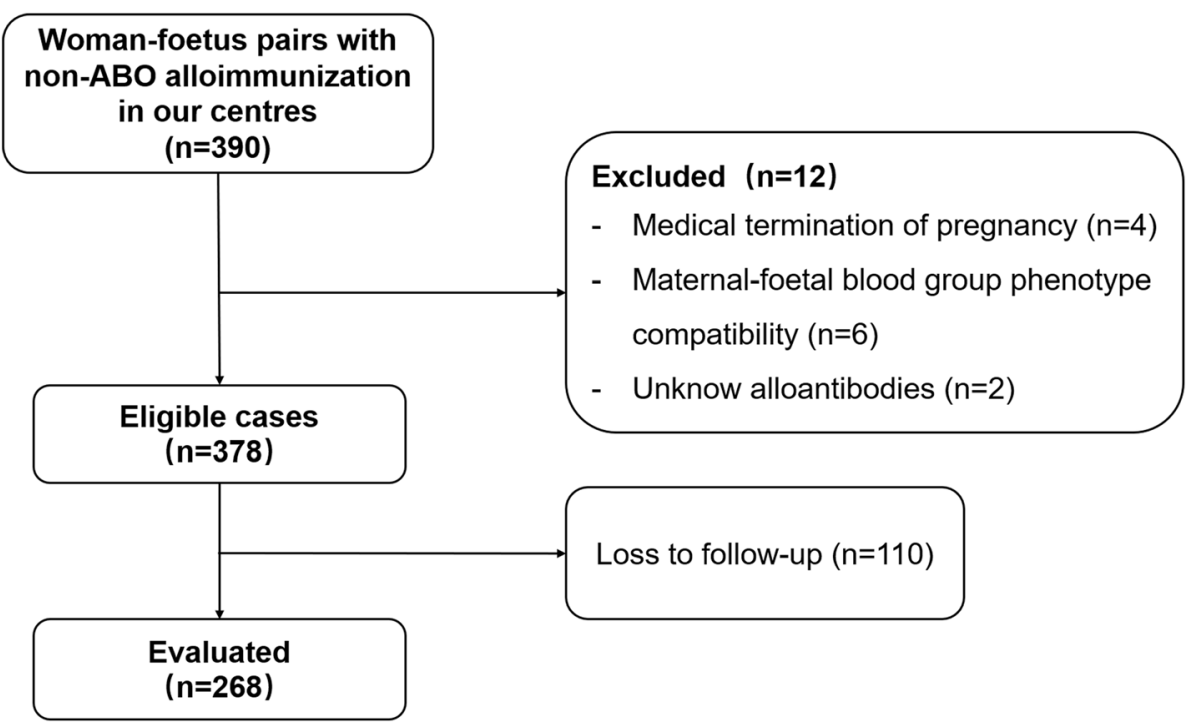

Fig. 1 Flow chart of the study participants

Table 1 Baseline data stratified by group

\begin{tabular}{|c|c|c|c|c|}
\hline & $\begin{array}{l}\text { Anti-D } \\
n=203\end{array}$ & $\begin{array}{l}\text { Anti-D combined with } \\
\text { others } \\
n=38\end{array}$ & $\begin{array}{l}\text { Other single- } \\
\text { antibody } \\
n=24\end{array}$ & $\begin{array}{l}\text { Other multiple } \\
\text { antibodies } \\
n=03^{+}\end{array}$ \\
\hline Maternal age (years) & $\begin{array}{l}31.5 \pm 4.3 \\
\text { (Unknown = } \\
11)\end{array}$ & $30.5 \pm 4.5$ & $29.3 \pm 4.2$ & $29.0 \pm 3.6$ \\
\hline P & & 0.368 & 0.125 & - \\
\hline Gravidity (times) & $\begin{array}{l}3(2-4) \\
\text { (Unknown =9) }\end{array}$ & $4(3-5)^{a}$ & $3(2-3.8)$ & $5(2.1-5)$ \\
\hline P & & 0.002 & 0.262 & - \\
\hline 1 & 8 & 1 & 3 & 0 \\
\hline 2 & 53 & 4 & 6 & 1 \\
\hline$>2$ & 133 & 33 & 15 & 2 \\
\hline Maternal transfusion history $n(\%)$ & $30(14.8)$ & $7(18.4)$ & $2(8.3)$ & $1(-)$ \\
\hline P & & 0.568 & 0.543 & - \\
\hline $\begin{array}{l}\text { Women with previously affected history } \\
n(\%)\end{array}$ & $\begin{array}{l}80(40.8) \\
(\text { Unknown = 7) }\end{array}$ & $24(63.2)^{a}$ & $14(58.3)$ & $2(-)$ \\
\hline P & & 0.011 & 0.075 & - \\
\hline Maternal-foetal ABO incompatibility $n(\%)$ & $\begin{array}{l}27(14.2) \\
(\text { Unknown = } \\
13)\end{array}$ & $4(10.5)$ & $\begin{array}{l}4(20.0) \\
(\text { Unknown = 4) }\end{array}$ & $0(-)$ \\
\hline P & & 0.545 & 0.507 & - \\
\hline \multicolumn{5}{|l|}{ Foetal sex } \\
\hline Female $n$ & 89 & 18 & 6 & 1 \\
\hline Male $n$ & 100 & 20 & 15 & 1 \\
\hline Unknown $n$ & 14 & 0 & 3 & 1 \\
\hline
\end{tabular}

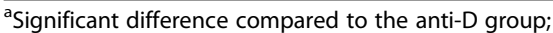

${ }^{\dagger}$ Can't calculate the $p$ value due to the small sample size in this group 
with other antibodies group had significantly more gravidities $(P=0.002)$ and a higher rate of previous affected history of HDFN $(P=0.011)$ than the anti-D group (Table 1).

\section{Incidence of HDF among cases with different types of antibodies}

There were $45.5 \%(122 / 268)$ of the foetuses suffering from HDF, and $34.7 \%(93 / 268)$ of them received IUTs. Anti-D was the most common antibody (82/122, 67.2\%) causing HDF, and 78.0\% (64/82) of patients underwent IUTs (Table 2). The cases of other single-antibody included anti-M $(n=18)$, anti-E $(n=03)$ and anti-Mur $(n=03)$. The cases of multiple antibodies included antiEc $(n=02)$ and anti-Ce $(n=01)$. The anti-M antibody in the MNS system was the second most common antibody outside of those in the Rh system.

Furthermore, different types of antibodies were associated with various risks of HDF. The incidence of severe HDF in the anti-D combined with other antibodies group was significantly higher than that in the anti-D group $(55.3 \%$ vs. $36.0 \%, P=0.025)$. The need for IUT in the anti-D combined with other antibodies group tended to be higher than that in the anti-D group ( $47.4 \%$ vs. $31.5 \%, P=0.059)$. The other single-antibody group had a significantly higher incidence of HDF $(62.5 \%$ vs. $40.4 \%$, $P=0.038)$, hydrops fetalis $(33.3 \%$ vs. $8.90 \%, P=0.002)$ and severe HDF $(62.5 \%$ vs. $36.0 \%, P=0.012)$ than the anti-D group (Table 2). The anti-M-associated risk of severe $\operatorname{HDF}(10 / 18,55.6 \%)$ was not significantly different from the anti-D-associated risk $(73 / 203,36.0 \%, P=$ $0.100)$. In 41 women with multiple antibodies, the red cell antigens of $\mathrm{ABO}$ blood group in 40 foetuses and $\mathrm{Rh}(\mathrm{D})$ antigens were known in all foetuses during the foetal or neonatal period, but only 21 of them had further identified other antigens ( $\mathrm{C}$ and $\mathrm{c}, \mathrm{E}$ and $\mathrm{e}$ ) in the $\mathrm{Rh}$ system and 1 case had further identified the $\mathrm{M}$ and $\mathrm{N}$ antigen. All these women in the anti-D combined others group had foetuses with positive $\mathrm{Rh}(\mathrm{D})$ antigen, $65.0 \%(13 / 20)$ of them had other cognate antigens. In the other multiple antibodies group, 2 foetuses those who had the same mother, had cognate antigens in $\mathrm{Rh}$ system.

There were 17 cases of intrauterine demise, including 11 due to anti-D, 2 due to anti-D with anti-C, 2 due to anti-M, 1 due to anti-Mur and 1 due to anti-Ec. Nine of these 17 foetuses did not survive after IUT. Demise in the other 8 cases was due to discontinuation of treatment and termination of the pregnancy because of severe foetal hydrops or severe foetal anaemia. Three foetuses were delivered by emergency caesarean but died

Table 2 The incidence of severe HDF between different types of antibodies

\begin{tabular}{|c|c|c|c|c|}
\hline & $\begin{array}{l}\text { Anti-D } \\
n=203\end{array}$ & $\begin{array}{l}\text { Anti-D combined with others } \\
n=38\end{array}$ & $\begin{array}{l}\text { Other single-antibody } \\
n=24\end{array}$ & $\begin{array}{l}\text { Other multiple antibodies } \\
n=03\end{array}$ \\
\hline HDF $n(\%)$ & $82(40.4)$ & $23(60.5)^{b}$ & $15(62.5)^{b}$ & $2(-)^{c}$ \\
\hline P & & 0.022 & 0.038 & - \\
\hline Severe $\operatorname{HDF}^{\mathrm{a}} n(\%)$ & $73(36.0)$ & $21(55.3)^{b}$ & $15(62.5)^{b}$ & $2(-)^{c}$ \\
\hline$P$ & & 0.025 & 0.012 & - \\
\hline Severe anaemia $n(\%)$ & $38(18.7)$ & $9(23.7)$ & $8(33.3)$ & 0 \\
\hline P & & 0.478 & 0.307 & - \\
\hline Hydrops fetalis $n(\%)$ & $18(8.9)$ & $3(7.9)$ & $8(33.3)^{b}$ & 0 \\
\hline P & & $>0.999$ & 0.002 & - \\
\hline Intrauterine demise $n(\%)$ & $12(5.9)$ & $2(5.3)$ & $3(12.5)$ & $1(-)^{c}$ \\
\hline P & & $>0.999$ & 0.202 & - \\
\hline IUT n(\%) & 64(31.5) & $18(47.4)$ & $10(41.6)$ & $1(-)^{c}$ \\
\hline$P$ & & 0.059 & 0.316 & - \\
\hline \multicolumn{5}{|l|}{ Survival rate of HDF } \\
\hline Foetuses & $55(67.1)$ & $18(78.3)$ & $12(80.0)^{b}$ & $1(-)^{c}$ \\
\hline$P$ & & 0.303 & 0.380 & - \\
\hline Neonates & $55(67.1)$ & $18(78.3)$ & $9(60.0)$ & $1(-)^{c}$ \\
\hline$P$ & & 0.303 & 0.595 & - \\
\hline
\end{tabular}

HDF haemolytic disease of the foetus; IUT intrauterine transfusion

${ }^{a}$ Foetuses may fall into more than 1 severe HDF defining category

${ }^{\mathrm{b}}$ Significant difference compared to the anti-D group

'Can't calculate the percentage because the denominator was less than 20

${ }^{s} \mathrm{Can}$ 't calculate the $p$ value due to the small sample size in this group 
during the neonatal period. The survival rate of HDF was not different among the 4 groups.

\section{Risk factors for HDF in foetuses with maternal alloimmunization}

As there were only 3 cases in the other multiple antibodies group, we did not include them into analysis. In the univariable analysis among the foetuses with maternal alloimmunization, four variables were associated with the occurrence of HDF (Table 3): more previous affected pregnancies per woman (OR 5.66, CI 3.5619.006), a higher maternal antibody titre (OR 1.00, CI 1.001-1.002), anti-D combined with others (compared with anti-D, OR 2.26, CI 1.114-4.594), and other singleantibody (compared with anti-D, OR 2.46, CI 1.0285.886). There were no significant differences between HDF and non-HDF foetuses with regard to maternal blood transfusion history or major $\mathrm{ABO}$ incompatibility. In the multivariable analysis, we included all seven variables. There were four variables associated with the occurrence of HDF: more previous affected pregnancies (OR 5.34, CI 3.156-9.036), a maternal transfusion history (OR 3.74 CI 1.219-11.464), a higher maternal antibody titre (OR 1.00, CI 1.001-1.002), and other singleantibody (compared with anti-D, OR 3.25, CI 1.04310.114).

\section{Foetal anaemia among groups with different types of antibodies}

Among the foetuses suffering from HDF, there were six cases of foetal demise before cordocentesis (3 with antiD, 2 with anti-M and 1 with anti-Ec). The pregnancies were terminated in two cases (1 with anti-Mur and 1 with anti-M) because of severe foetal hydrops without cordocentesis. One foetus (anti-DC-related HDF) was delivered via emergency caesarean at $34^{+5}$ weeks of gestation because of foetal distress and a rapid increase in the antibody titre. Therefore, a total of 113 foetuses with haemolytic anaemia confirmed by cordocentesis were included in the analysis. The distribution of antibodies that resulted in foetal haemolytic anaemia is shown in Fig. 2. There was no significant difference in the distribution of the degree of foetal anaemia among the four groups $(P=0.466)$. The antibodies in the Rh blood group system were the most common antibodies leading to foetal anaemia $(92.0 \%, 104 / 113)$, followed by the antibodies in the MNS blood group system, including anti-M $(n=07)$ and anti-Mur $(n=02)$. Anti-D was the most common antibody that caused foetal anaemia. It was effective alone $(79 / 113,69.9 \%)$ or in combination with anti-C (15 cases) or anti-E (7 cases) $(22 / 113,19.5 \%)$ with regard to causing foetal haemolytic anaemia. Anti-E caused one case of severe anaemia, one case of mild anaemia and one case of moderate anaemia with anti-c.

Regarding the characteristics of foetuses with anaemia and their mothers, those who had anti-D combined with other antibodies had more pregnancies affected by HDFN than those who had anti-D alone [ $1(0-1)$ vs. $2(1-2), P=$ $0.002]$. However, there was no significant difference in the foetal haemoglobin concentration, haematocrit, reticulocyte count and percentage, or gestational age at birth between these two groups (Table 4). The maximal antibody titre was significantly lower in the other single-antibody group [1:32 (1:8 - 1:256)], as well as that of anti-M [1:8 (1: $8-1: 64)]$, than those in the anti-D group [1:512 (1:512-1: 2048)] $(P<0.05)$. In addition, the foetuses in the other single-antibody group had a significantly lower

Table 3 Risk factors for HDF in foetuses with maternal alloimmunization

\begin{tabular}{|c|c|c|c|c|c|c|}
\hline & $\begin{array}{l}\text { HDF } \\
(n=120)\end{array}$ & $\begin{array}{l}\text { No HDF } \\
(n=145)\end{array}$ & $P$ & $\begin{array}{l}\text { Univariable OR } \\
(95 \% \mathrm{Cl})\end{array}$ & $P$ & $\begin{array}{l}\text { Multivariable OR } \\
(95 \% \mathrm{Cl})\end{array}$ \\
\hline Previous affected pregnancies per woman ${ }^{a}$ & $1(0-2)$ & $0(0-0)$ & $<0.001$ & $5.66(3.561-9.006)$ & $<0.001$ & 5.34(3.156-9.036) \\
\hline Maternal transfusion history, n (\%) & 18(15.0) & $21(14.5)$ & 0.906 & $0.96(0.485-1.898)$ & 0.021 & $3.74(1.219-11.464)$ \\
\hline Maternal antibody titre ${ }^{a}$ & $1: 512(1: 256-1: 1792)$ & $1: 64(1: 16-1: 256)^{c}$ & $<0.001$ & $1.00(1.001-1.002)$ & $<0.001$ & $1.00(1.001-1.002)$ \\
\hline Major ABO incompatibility, n (\%) & $9(7.7)^{d}$ & $26(19.8)^{e}$ & 0.319 & $0.72(0.376-1.375)$ & 0.488 & $0.73(0.303-1.767)$ \\
\hline \multicolumn{7}{|l|}{ Types of maternal antibody } \\
\hline Anti-D, n (\%) & $82(68.3)$ & 121(83.4) & - & - & - & - \\
\hline Anti-D combined with others, $\mathrm{n}(\%)$ & 23(19.1) & 15(10.3) & 0.024 & $2.26(1.114-4.594)$ & 0.598 & $0.74(0.246-2.246)$ \\
\hline Other single-antibody, n (\%) & $15(12.5)$ & $9(4.8)$ & 0.043 & $2.46(1.028-5.886)$ & 0.042 & $3.25(1.043-10.114)$ \\
\hline
\end{tabular}

$H D F$ haemolytic disease of the foetus

${ }^{\text {a } D a t a ~ p r e s e n t ~ a s ~ m e d i a n ~(25 t h ~-~ 75 t h ~ q u a r t i l e s) ~}$

${ }^{\mathrm{b}}$ The multivariable analysis included the following risk factors for analysis: previous affected pregnancies per woman, maternal transfusion history, maternal

antibody titre, major $\mathrm{ABO}$ incompatibility and types of maternal antibody (anti-D, other single-antibody)

${ }^{C}$ Assessed in 135/145 (93.1\%) foetuses, missing values for 10

${ }^{\mathrm{d}}$ Assessed in 117/120 (97.5\%) foetuses, missing values for 3

eAssessed in 131/145 (90.3\%) foetuses, missing values for 14 


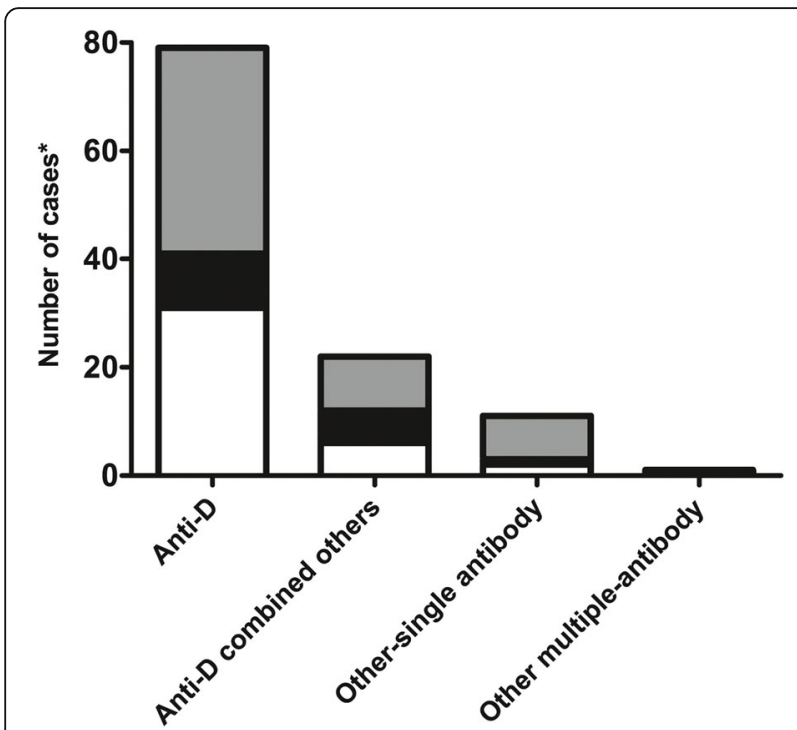

Fig. 2 The distribution of antibodies that resulted in foetal haemolytic anaemia; White: mild anaemia; Black: moderate anaemia; Gray: severe anaemia. *There were six cases of foetal demise before cordocentesis (3 with anti-D, 2 with anti-M and 1 with anti-Ec). The pregnancies were terminated in three cases ( 1 with anti-DC, 1 with anti-Mur and 1 with antiM) without cordocentesis

reticulocyte count $\left(142.1 \pm 122.6 \times 10^{9} / \mathrm{L}\right.$ vs. $303.0 \pm$ $\left.97.3 \times 10^{9} / \mathrm{L}, P=0.007\right)$ and reticulocyte percentage $[8.5$ $(4.2-17.1) \%$ vs. $15.7(10.1-22.8) \%, P=0.015]$ but a higher number of IUTs [5 (3-5) vs. $2(1-4), P=0.007]$ than those in the anti-D group (Table 4).

\section{Risk factors for severe HDF in foetuses with Rh(D) alloimmunization}

In the univariable analysis among the foetuses affected by anti-D, including those combined with other antibodies, we included five variables: foetal sex, maternal titre, diagnostic gestational age, foetal reticulocyte count and ani-D combined with other antibodies in the analysis (Table 5). Two variables were significantly associated with the occurrence of severe HDF: an early diagnostic gestation age of HDF (OR 0.71; CI 0.544-0.934) and a higher reticulocyte count (OR 1.01; CI 1.0031.022). In the multivariable analysis, only one variable was associated with the occurrence of severe HDF: a higher reticulocyte count (OR 1.01; CI 1.001-1.026). The foetal sex, maternal antibody titre, diagnostic gestation age and anti-D combined with other antibodies in mothers were not the independent risk factors for severe HDF.

\section{Severe HDF-free survival}

Totally $45.5 \%(122 / 268)$ of the foetuses in our study were affected by maternal alloimmunization and developed HDF. We performed a survival analysis with the Kaplan-Meier method to determine the gestational age interval free from severe HDF (Fig. 3). As the only 2 foetuses in the other multiple antibodies group were from the same pregnant woman, we did not include them in the analysis. The median survival times free from severe HDF were significantly different among the three groups $(P=0.028)$. In the anti-D group, $11.0 \%$ of foetuses did not develop severe HDF (Table 2). The median survival time free from severe HDF was 29.6 weeks, and the longest survival time free from severe HDF was 37.9 weeks in this group. When compared to the anti-D combined with other antibodies group, the median survival time was not significantly different ( 29.6 weeks vs. 26.7 weeks, $P=0.128$ ). However, the median survival time free from severe HDF in the other single-antibody group was

Table 4 Characteristics of anaemic foetuses in the three groups

\begin{tabular}{|c|c|c|c|c|c|}
\hline & $\begin{array}{l}\text { Anti-D } \\
n=79\end{array}$ & $\begin{array}{l}\text { Anti-D combined with others } \\
n=22\end{array}$ & $P$ & $\begin{array}{l}\text { Other single-antibody } \\
n=11\end{array}$ & $P$ \\
\hline Previously affected pregnancies per women & $1(0-1)$ & $2(1-2)$ & $0.002^{*}$ & $1(0-1)$ & 0.990 \\
\hline Maternal antibody titre & $1: 512(1: 512-1: 2048)$ & $1: 768(1: 256-1: 2560)$ & 0.561 & $1: 32(1: 8-1: 256)$ & $<0.001^{*}$ \\
\hline Haemoglobin $(g / L)^{a}$ & $68.4 \pm 26.6$ & $67.7 \pm 23.6$ & 0.908 & $50.2 \pm 23.1$ & $0.033^{*}$ \\
\hline Haematocrit (\%) ${ }^{\mathrm{a}}$ & $20.9 \pm 7.7$ & $20.5 \pm 6.3$ & 0.831 & $15.2 \pm 6.6$ & $0.023^{*}$ \\
\hline Reticulocyte count $\left(\times 10^{\wedge} 9 /\llcorner)^{a}\right.$ & $303.0 \pm 97.3^{c}$ & $331.3 \pm 104.9$ & 0.245 & $142.1 \pm 122.6^{d}$ & $0.007^{*}$ \\
\hline Reticulocyte percentage $(\%)^{b}$ & $15.7(10.2-22.8)^{c}$ & 19.9(13.6-31.3) & 0.168 & $8.5(4.2-17.1)^{d}$ & $0.015^{*}$ \\
\hline Hydrops, $n(\%)$ & 15(19.0) & $3(13.6)$ & 0.756 & $3(33.3)$ & 0.235 \\
\hline Number of IUTs ${ }^{c}$ & $2(1-4)$ & $3.5(1-5)$ & 0.167 & $5(3-5)$ & $0.007^{*}$ \\
\hline Gestational age at birth ${ }^{\mathrm{b}, \mathrm{c}}$ & $35.0(33.9-36.6)$ & $36.0(33.4-36.9)$ & 0.586 & $35.0(33.2-35.6)$ & 0.331 \\
\hline
\end{tabular}

IUT intrauterine transfusion

* Significant difference compared to the anti-D group

${ }^{\text {a }}$ Data presented as the mean \pm SD

${ }^{b}$ Data present as median (25th -75 th quartiles)

cAssessed in 72/79 (91.1\%) foetuses, missing values for 7

${ }^{\mathrm{d}}$ Assessed in $6 / 9$ (66.7\%) foetuses, missing value for 3 
Table 5 The predictors of severe HDF in foetuses with anti-D and/or combined other antibodies

\begin{tabular}{|c|c|c|c|c|c|c|}
\hline & $\begin{array}{l}\text { Severe HDF } \\
(n=91)\end{array}$ & $\begin{array}{l}\text { No severe HDF } \\
(n=10)\end{array}$ & $P$ & $\begin{array}{l}\text { Univariable OR } \\
(95 \% \mathrm{Cl})\end{array}$ & $P$ & $\begin{array}{l}\text { Multivariable } \mathrm{OR}^{\mathrm{c}} \\
(95 \% \mathrm{Cl})\end{array}$ \\
\hline Female, n (\%) & $42(46.2)$ & $7(70.0)$ & 0.446 & $0.60(0.157-2.257)$ & 0.067 & $0.17(0.026-1.138)$ \\
\hline Maternal antibody titre $\mathrm{a}^{\mathrm{a}}$ & $1: 1024(1: 512-1: 2048)$ & $1: 320(1: 56-1: 1024)$ & 0.067 & $1.00(1.000-1.003)$ & 0.671 & $1.00(0.999-1.002)$ \\
\hline Gestational age at diagnosis, weeks $^{a}$ & $28.0(23.3-32.1)$ & $33.6(32.7-34.0)$ & 0.014 & $0.71(0.544-0.934)$ & 0.098 & $0.76(0.543-1.053)$ \\
\hline Reticulocyte count ${ }^{\mathrm{b}}\left(10^{9} / \mathrm{L}\right)$ & $318.4 \pm 98.8$ & $226.7 \pm 59.4$ & 0.012 & $1.01(1.003-1.022)$ & 0.041 & $1.01(1.001-1.026)$ \\
\hline Anti-D combined with others, $\mathrm{n}(\%)$ & $21(23.1)$ & $1(10.0)$ & 0.359 & $2.70(0.323-22.556)$ & 0.834 & $1.29(0.119-14.052)$ \\
\hline
\end{tabular}

HDF haemolytic disease of the foetus; OR odds ratio

${ }^{\mathrm{a}}$ Data present as the median (25th -75 th quartiles)

${ }^{b}$ Data presented as the mean \pm SD

'The multivariable analysis included the following risk factors for analysis: foetal sex, maternal antibody titre, gestational age at diagnosis, reticulocyte count and anti-D combined with others

significantly shorter than that in the anti-D group $(26.2$ weeks vs. 29.6 weeks, $P=0.012$ ), suggesting that the foetuses in the other single-antibody group might be affected by maternal alloimmunization earlier.

\section{Discussion}

The distribution of maternal alloimmunization and HDFN varies in different countries and populations[7, 13]. Thus far, the distribution of HDF antibodies in the Chinese population has not been reported. In Guangdong Province of China, the percentage of pregnant women with red cell alloimmunization was $0.27 \% \sim 1.05 \%$ [14]. In our study, we analysed 268 pregnant women with red cell alloimmunization and their foetuses, including 122 foetuses with haemolytic disease, to characterize the antibody distribution of HDF in a Chinese population. Anti-D was still the most common cause of $\operatorname{HDF}(67.2 \%, 82 / 122)$. However, in our study, no case of HDF due to isolated anti-c was found, which is the secondary cause of severe HDF after

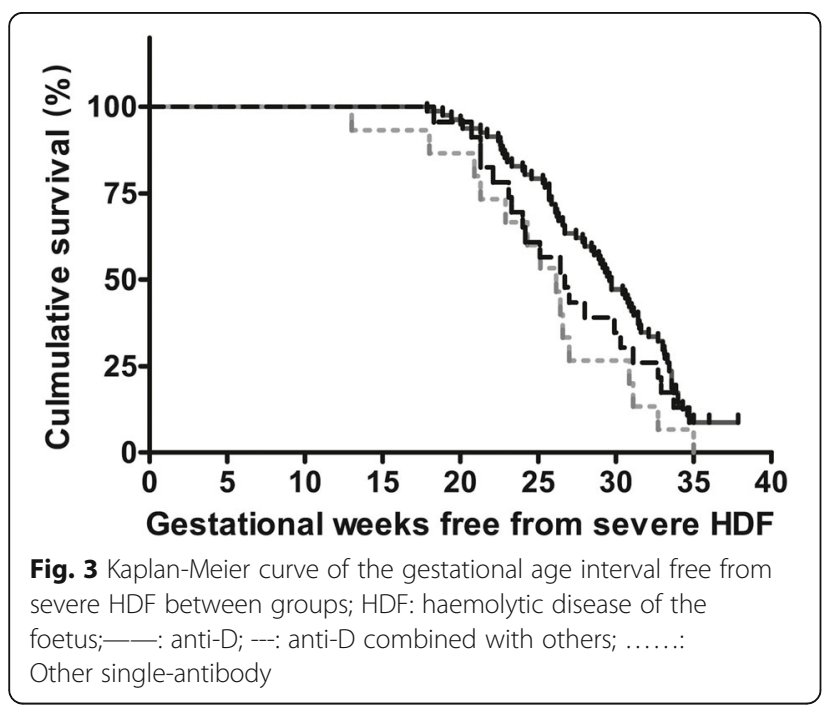

anti-D in the Caucasian population[15]. The difference might be due to the significantly lower frequency of the $\mathrm{c}$ antigen in the Chinese population than in the Caucasian population[16]. Similarly, there was no case of anti-K HDF detected in our study, nor were there any women who were positive for the anti-K antibody. Due to the extremely low frequency of the $\mathrm{K}$ antigen in the Kell blood group system in the Chinese population, anti-K antibody positivity is extremely rare[7], and anti-K-related HDN has rarely been reported[17]. Therefore, the distribution of HDF-associated antibodies in the Chinese population is different from that in the Caucasian population.

Moreover, we found that anti-M was the most common non- $\mathrm{Rh}(\mathrm{D})$ antibody, accounting for $55.5 \%$ of the incidence of HDF (10/18). Very few reports have causally linked anti-M antibody positivity with HDFN in a Caucasian population[18]. Over the past two decades, antiM-related HDFN has mostly been reported in Asian ethnic groups, especially in Japanese[19] and Chinese populations[20,21], and it has been reported to result in severe foetal anaemia, hydrops fetalis, stillbirth and neonatal death. A previous study found that $88.6 \%$ of antiM-related HDFN cases occurred in Asian populations[21], indicating the high pathogenicity of IgG anti$\mathrm{M}$ in Chinese people. Even though our tertiary prenatal centre provided a relatively higher incidence of HDF due to anti-M, our results suggested that the risk of anti-Massociated severe HDFN in the Chinese population might be high, with $60.0 \%(6 / 10)$ receiving IUTs and 2 cases of intrauterine demise due to the lack of timely treatment. In addition, the antibody titre of anti-M was significantly lower than that of anti-D, indicating that anti-M can cause severe HDF even at low titres. The lower reticulocyte count indicated incompatible erythropoiesis with severe anaemia [21], which was also found in neonatal cases[19]. These results might be explained by the suppression of red cell development from erythroid precursor cells [22, 23]. As a consequence, anti-Mrelated HDFN can have a negative result of direct antihuman globulin test (direct Coombs test) [19], making 
the diagnosis of anti-M-related HDFN difficultly and often missed.

The presence of multiple antibodies seemed to increase the risk of HDF-associated morbidity without influencing the severity of foetal anaemia. The incidence of severe HDF was significantly higher when the pregnant women had anti-D combined with other antibodies, which was consistent with previous studies [24-26]. However, after the logistic regression analysis, anti-D combined with other antibodies was not an independent risk factor for HDF. Moreover, among the anaemic foetuses, no significant difference was found in the foetal haemoglobin concentration or gestational age at diagnosis between the anti-D group and the anti-D combined with other antibodies group. The similar reticulocyte counts and percentages between these two groups indicated similar haematopoietic conditions. Some studies reported that neither the foetal anaemia severity nor the gestational age at first IUT was influenced by anti-D with other antibodies[10, 27]. In the logistic regression analysis of anaemic foetuses affected by $\mathrm{Rh}(\mathrm{D})$ alloimmunization, anti-D combined with other antibodies was not a risk factor for severe HDF in either univariate analysis or multivariate analysis. These results indicated that the high incidence of HDF in the anti-D combined with other antibodies group was affected by other confounding factors. Furthermore, we also found that women with multiple antibodies had a higher rate of previous HDFN and more affected pregnancies than those with only anti-D. These results might suggest that the more often an $\mathrm{Rh}(\mathrm{D})$-negative woman is exposed to an $\mathrm{Rh}(\mathrm{D})$ incompatible foetus, the higher chances of generating additional antibodies are, leading to a more aggressive immune response and cumulative effect and increasing the risk of haemolysis and the chance of developing severe HDF. For the foetuses affected by maternal multiple antigens, $68.2 \%$ of the foetuses, those who identified other Rh blood group phenotypes, had cognate antigens. The additional antibody of the remaining cases might occur from previously affected pregnancy or the stimulation from nature. These further indicated as anti-D still played a dominant role in haemolysis, the severity of HDF was not significantly different regardless of whether anti-D was present alone or in combination with other antibodies. Therefore, when a pregnant woman has multiple antibodies and a history of multiple HDFN affected pregnancies, her foetus might have a higher risk of developing severe HDF and should be closely monitored during the antenatal period.

In the regression analysis, we found that a high maternal antibody titre, more previously affected pregnancies, and other single-antibody were independent risk factors for the occurrence of HDF. Even though in some alloimmunizations, a low antibody titre can cause severe
HDFN[28], a high titre suggests a more active immune response, increasing the risk of HDF. Moreover, a history of multiple affected pregnancies might result in the generation of a larger amount and longer duration of antibodies [29], which can cross the placenta to cause the disease in the foetal period. In $\mathrm{Rh}(\mathrm{D})$ alloimmunization, once foetal anaemia occurred, the antibody titre could not predict the risk of severe HDF. A higher reticulocyte count was an independent risk factor for severe HDF. The more severe the anaemia and the more active the erythropoiesis were, the more severe the disease, indicating the need for intrauterine intervention. In the multivariable analysis, we also found that a transfusion history in the mother might be associated with HDF. According to the Technical Specifications of Clinical Blood Transfusion in China, no blood types other than $\mathrm{ABO}$ and $\mathrm{Rh}(\mathrm{D})$ are regularly detected before blood transfusion. Due to the scarcity of $\mathrm{Rh}(\mathrm{D})$ negative blood in China, $\mathrm{Rh}(\mathrm{D})$ negative individuals might receive $\mathrm{Rh}(\mathrm{D})$ positive red blood cells in some medical emergencies. As the volume of the blood transfusion is larger than the volume of foetomaternal haemorrhage and is enough to sensitize the individual[29], sensitized women would develop more aggressive alloimmunization during pregnancy. Therefore, women with a previous blood transfusion history might have a higher risk of having a foetus with HDF.

The Kaplan-Meier analysis was conducted to determine the severe HDF-free interval and compare the intervals among groups with different antibodies, and the results provided a clinical reference to support the estimation of the gestational age at the onset of severe HDF and the appropriate time for clinical intervention. The significant difference in the median survival time among the groups indicated that the onset time of severe HDF varied based on the types of antibodies. The other single-antibody group had a significantly shorter survival time, providing evidence that foetuses affected by other single-antibody group, mainly anti-M, might develop severe HDF earlier than those affected by anti-D alone. This can be explained by the earlier development of antigens in the MNS system than in the Rh system during foetal development and erythropoiesis[30].

There were still some limitations of our study. Our centre is a tertiary prenatal care centre, and the patients therein might have a higher risk for HDFN, more severe HDFN, and more severe associated complications. Therefore, the morbidity and mortality rates might be higher among patients in this study than among individuals throughout the country. Because of the insufficient sample size for specific non-anti-D antibodies, we could not compare the differences between specific antibodies, especially in terms of multiple other antibodies. As the inadequate realization of the maternal alloimmunization 
with multiple antibodies in the early stage of our centre, not all the foetuses were identified the non- $\mathrm{Rh}(\mathrm{D})$ blood phenotype, and gave a limited analysis for multiple maternal antibodies and foetal cognate antigens. What's more, the survival curves between the anti-D and anti-D combined with other antibodies groups intersected, indicating that confounding factors might have affected the statistical results. As the period free from severe HDF can be influenced by the frequency of foetal investigations, gestational age at the time of prenatal consultation, and awareness of the disease, which varied over the 15-year period, the results of the Kaplan-Meier analysis may not be accurate for all antibody patterns. More prospective studies are needed for further accurate investigation on different alloimmunizations.

\section{Conclusions}

The antibody distribution for HDF in China is different from that in Western countries. Other single non- $\mathrm{Rh}(\mathrm{D})$ antibodies could increase the risk of HDF, and anti-D combined with other antibodies is not an independent risk factor of HDF and would not influence the severity of foetal anaemia compared with anti-D alone.

\section{Abbreviations}

Cl: Confidence interval; HDF: Haemolytic disease of the foetus; HDFN: Haemolytic disease of the foetus and new-born; IAT: Indirect antiglobulin test; IgG: Immunoglobin G; IgM: Immunoglobin M; IUT: Intrauterine transfusion; MoM: Multiple of the median; OR: Odds ratio; RBC: Red blood cell

\section{Acknowledgements}

Not applicable.

\section{Authors' contributions}

S.L. designed and performed the research, analysed the data and wrote the paper; ZM.H. \& YM. L. performed the research; YL. J. \& GP. L. made contributions to alloantibody identification and analysis. Y. G. and Q. F. designed the research and made major revisions to the paper. All authors have read and approved the manuscript.

\section{Funding}

This work was supported by the National Natural Science Foundation of China (No. 81671479) and the China Postdoctoral Science Foundation (No. 2018M640864). The funders had no role in the study design, data collection and analysis, decision to publish, or preparation of the manuscript.

\section{Availability of data and materials}

The datasets used and/or analysed during the current study are available from the corresponding author on reasonable request.

\section{Ethics approval and consent to participate}

All procedures performed in the study involving human participants were performed in accordance with the ethics standards of the institutional and/ or national research committee and with the 1964 Helsinki declaration and its later amendments or comparable ethics standards. All the patients indicated consent by written informed consent before the medical intervention. The study was approved by the ethics committee of the Sixth Affiliated Hospital of Sun Yat-sen University in Guangzhou, China(2020ZSYLEC-056). Data was collected from part of routine antenatal management and neonatal care, and personal information was only accessible to the study team.

\section{Consent for publication}

Not applicable.

\section{Competing interests}

The authors declare that they have no competing interests.

\section{Author details}

${ }^{1}$ Department of Obstetrics, the Sixth Affiliated Hospital of Sun Yat-sen University, 510655 Guangzhou, Guangdong, China. ${ }^{2}$ Foetal Medicine Centre, Department of Obstetrics and Gynaecology, the First Affiliated Hospital of Sun Yat-sen University, Guangdong 51000 Guangzhou, China. ${ }^{3}$ Insititute of Clinical Blood Transfusion, Guangzhou Blood Centre, 510095 Guangzhou, China.

Received: 24 March 2020 Accepted: 3 September 2020

Published online: 16 September 2020

\section{References}

1. de Haas M, Thurik FF, Koelewijn JM, van der Schoot CE. Haemolytic disease of the fetus and newborn. Vox Sang. 2015;109(2):99-113.

2. de Haas M, Finning K, Massey E, Roberts DJ. Anti-D prophylaxis: past, present and future. Transfus Med. 2014;24(1):1-7.

3. Qureshi H, Massey E, Kirwan D, Davies T, Robson S, White J, Jones J, Allard S. BCSH guideline for the use of anti-D immunoglobulin for the prevention of haemolytic disease of the fetus and newborn. Transfus Med. 2014;24(1):8-20.

4. Chandrasekar A, Morris KG, Tubman TR, Tharma S, McClelland WM. The clinical outcome of non-RhD antibody affected pregnancies in Northern Ireland. Ulster Med J. 2001;70(2):89-94.

5. Koelewijn JM, Vrijkotte TGM, van der Schoot CE, Bonsel GJ, de Haas M. Effect of screening for red cell antibodies, other than anti-D, to detect hemolytic disease of the fetus and newborn: a population study in the Netherlands. Transfusion. 2008;48(5):941-52.

6. Healsmith S, Savoia H, Kane SC. How clinically important are non-D Rh antibodies? Acta Obstet Gynecol Scand. 2019;98(7):877-84.

7. Chen C, Tan J, Wang L, Han B, Sun W, Zhao L, Huang C, Tan B, Qin L. Unexpected red blood cell antibody distributions in Chinese people by a systematic literature review. Transfusion. 2016;56(4):975-9. .

8. Yang R, Li G, He X, Ren M. Analysis of neonatal hemolytic disease caused by Rh, MNS blood type system irregular antibodies[article in Chinese]. J Clin Hematol. 2019;32(01):109-12

9. Yang X, Chen FZ, Hong Q. Analysis of Screening Results in 501 Newborns with Hemolytic Disease[article in Chinese]. J Exp Hematol Chin. 2019;27(1):192-6.

10. Phung TV, Houfflin-Debarge V, Ramdane N, Ghesquiere L, Delsalle A, Coulon C, Subtil D, Vaast P, Garabedian C. Maternal red blood cell alloimmunization requiring intrauterine transfusion: a comparative study on management and outcome depending on the type of antibody. Transfusion. 2018;58(5):1199-205.

11. Moise KJ Jr. Management of rhesus alloimmunization in pregnancy. Obstet Gynecol. 2008;112(1):164-76.

12. Mari G, Norton ME, Stone J, Berghella V, Sciscione AC, Tate D, Schenone MH, Med SM-F. Society for Maternal-Fetal Medicine (SMFM) Clinical Guideline \#8: The fetus at risk for anemia-diagnosis and management. Am J Obstet Gynecol. 2015;212(6):697-710.

13. Webb J, Delaney M. Red Blood Cell Alloimmunization in the Pregnant Patient. Transfus Med Rev. 2018;32(4):213-9.

14. Wu Y, Liu Y, Liu X, Liu J, Wu Y, Chen B, Liang Y. Distribution of irregular antibodies of erythrocyte blood group in 30800 Han patients and 4200 pregnant women. J Fourth Mil Med Univ[article in Chinese]. 2007;28(10): 922-5.

15. Kaushansky K, Lichtman MA, Prchal JT, Levi MM, Press OW, Burns LJ, Caligiuri M. Williams Hematology. 9 ed. New York: McGraw-Hill Education; 2015

16. Yu Y, Ma C, Sun X, Guan X, Zhang X, Saldanha J, Chen L, Wang D. Frequencies of red blood cell major blood group antigens and phenotypes in the Chinese Han population from Mainland China. Int J Immunogenet. 2016;43(4):226-35.

17. Li XF, Diao XQ, Liu XL, Lv HJ, Cui ZH. Study on the implication of anti-K antibody in hemolytic disease of the newborn-one case report[article in Chinese]. Chin J Blood Transfus. 2015;28(9):1115-7.

18. Stetson B, Scrape S, Markham KB. Anti-M Alloimmunization: Management and Outcome at a Single Institution. Am J Perinatol Rep. 2017;7(4):e205-10. 
19. Yasuda H, Ohto H, Nollet KE, Kawabata K, Saito S, Yagi Y, Negishi Y, Ishida A. Hemolytic disease of the fetus and newborn with late-onset anemia due to anti-M: a case report and review of the Japanese literature. Transfus Med Rev. 2014;28(1):1-6.

20. Gao XY, Huang H, Li LD. Hemolytic disease of neonates due to anti-M: report of one case and review of reports of 21 cases [article in Chinese]. Chin J Pediatr. 2009;47(9):648-52.

21. Li S, Mo C, Huang L, Shi X, Luo G, Ji Y, Fang Q. Hemolytic disease of the fetus and newborn due to alloanti-M: three Chinese case reports and a review of the literature. Transfusion. 2019;59(1):385-95.

22. Ishida A, Ohto H, Yasuda H, Negishi Y, Tsuiki H, Arakawa T, Yagi Y, Uchimura D, Miyazaki T, Ohashi W, et al. Anti-M antibody induced prolonged anemia following hemolytic disease of the newborn due to erythropoietic suppression in 2 siblings. J Pediatr Hematol Oncol. 2015;37(6):375-7.

23. Nolan B, Hinchliffe R, Vora A. Neonatal pure red cell aplasia due to maternal anti-M. Blood. 2000;96(11):8A. .

24. Markham KB, Rossi KQ, Nagaraja HN, O'Shaughnessy RW. Hemolytic disease of the fetus and newborn due to multiple maternal antibodies. Am J Obstet Gynecol. 2015;213(1):68.e61-e65.

25. Spong CY, Porter AE, Queenan JT. Management of isoimmunization in the presence of multiple maternal antibodies. Am J Obstet Gynecol. 2001;185(2): 481-4.

26. Nordvall M, Dziegiel M, Hegaard HK, Bidstrup M, Jonsbo F, Christensen B, Hedegaard M. Red blood cell antibodies in pregnancy and their clinical consequences: synergistic effects of multiple specificities. Transfusion. 2009; 49(10):2070-5.

27. Walsh CA, Russell N, McAuliffe FM, Higgins S, Mahony R, Carroll S, McParland P. Relationship between maternal antibody type and antenatal course following intrauterine transfusion for red cell alloimmunisation. Eur J Obstet Gynecol Reprod Biol. 2013;171(2):235-9.

28. Wikman A, Edner A, Gryfelt G, Jonsson B, Henter Jl. Fetal hemolytic anemia and intrauterine death caused by anti-M immunization. Transfusion. 2007; 47(5):911-7. .

29. Fasano RM, Hendrickson JE, Luban NLC. Alloimmune Hemolytic Disease of the Fetus and Newborn. In: Kaushansky K, Lichtman MA, Prchal JT, Levi MM, Press OW, Burns LJ, Caligiuri M, editors. Williams Hematology. 9e ed. New York: McGraw-Hill Education; 2015.

30. Hu JP, Liu J, Xue FM, Halverson G, Reid M, Guo AQ, Chen LX, Raza A, Galili $\mathrm{N}$, Jaffray J, et al. Isolation and functional characterization of human erythroblasts at distinct stages: implications for understanding of normal and disordered erythropoiesis in vivo. Blood. 2013;121(16):3246-53.

\section{Publisher's Note}

Springer Nature remains neutral with regard to jurisdictional claims in published maps and institutional affiliations.

Ready to submit your research? Choose BMC and benefit from:

- fast, convenient online submission

- thorough peer review by experienced researchers in your field

- rapid publication on acceptance

- support for research data, including large and complex data types

- gold Open Access which fosters wider collaboration and increased citations

- maximum visibility for your research: over $100 \mathrm{M}$ website views per year

At BMC, research is always in progress.

Learn more biomedcentral.com/submissions 